\title{
Effect of Incorporation of Brassica spp. Residues on Population Densities of Soilborne Microorganisms and on Damping-off and Fusarium Wilt of Watermelon
}

\author{
Samuel M. C. Njoroge, University of California, Davis, c/o USDA ARS Salinas, CA 93905; Melissa B. Riley, \\ Clemson University, Department of Entomology, Soils, and Plant Sciences, Clemson, SC 29634; and Anthony P. \\ Keinath, Clemson University, Coastal Research and Education Center, Charleston, SC 29414
}

\begin{abstract}
Njoroge, S. M. C., Riley, M. B., and Keinath, A. P. 2008. Effect of incorporation of Brassica spp. residues on population densities of soilborne microorganisms and on damping-off and Fusarium wilt of watermelon. Plant Dis. 92:287-294.

Incorporating Brassica spp. residue to reduce populations of soilborne fungi and manage damping-off and Fusarium wilt of watermelon (Citrullus lanatus var. lanatus) was studied in two field experiments. Treatments included incorporating flowering Brassica napus cv. Dwarf Essex canola or $B$. juncea $\mathrm{cv}$. Cutlass mustard and laying black polyethylene mulch at incorporation or 1 month after incorporation, methyl bromide, and a nontreated control. In both years, glucosinolates were identified and quantified in the shoots and roots of the flowering plants. In both years, the total concentration of glucosinolates incorporated per square meter was significantly higher for $B$. juncea than for B. napus. Isothiocyanates were inconsistently detected in the amended soils and none were detected more than 12 days postincorporation. After incorporation in 2004 and 2005, amended plots had higher populations of Fusarium oxysporum and Pythium spp. than the methyl bromide treatment, and in some treatments, populations were higher than in the control. Fluorescent Pseudomonas spp. were not suppressed in amended soils, and their populations were significantly higher in some amended treatments than those in methyl bromide-treated soils or nontreated control soils. Incidence of damping-off and severity of Fusarium wilt on seedless watermelon cv. Tri-X 313, which is susceptible to Fusarium wilt, were not consistently lower in brassica-amended soils or methyl bromide-treated plots than in nontreated control plots. Therefore, under spring conditions and methods used in this study, neither biofumigation nor methyl bromide fumigation in coastal South Carolina was an effective disease management tool for two soilborne pathogens of watermelon.
\end{abstract}

Additional keywords: Fusarium oxysporum f. sp. niveum, Rhizoctonia solani, Sclerotium rolfsii

Fusarium wilt of watermelon (Citrullus lanatus var. lanatus (Thunb.) Matsum. \& Nakai) is caused by Fusarium oxysporum Schlechtend.:Fr. f. sp. niveum (E.F. Sm.) W.C. Snyder \& H.N. Hans. $(7,12,42,43)$. Three races $(0,1$, and 2$)$ of $F$. oxysporum $\mathrm{f}$. sp. niveum have been described. Incidence of Fusarium wilt of watermelon is significantly correlated with inoculum density of F. oxysporum f. sp. niveum, regardless of the race structure of the pathogen in the field (42). It is, therefore, important to reduce inoculum density prior to planting. In the past, using methyl bromide as a preplant fumigant has been a valuable tool for management of soilborne pathogens, and it has been used to manage Fusarium wilt of watermelon. Currently, use of methyl bromide in the United States only is available to growers under critical use exemptions. Moreover, preplant soil fumi-

Corresponding author: S. M. C. Njoroge

E-mail: snjoroge@ucdavis.edu

Accepted for publication 24 September 2007.

doi:10.1094/PDIS-92-2-0287

(C) 2008 The American Phytopathological Society gation has human and environmental risks and is costly (43).

Alternatives to methyl bromide for managing soilborne pathogens are needed, and the evaluation of promising methods for adaptation to local situations is important. Biofumigation may be one promising management method. Biofumigation refers to the suppression of soilborne pests and pathogens by biocidal compounds released in soil when glucosinolates, thioglucoside compounds in brassica crops, are hydrolyzed (15).

Fusarium spp. are reported to be sensitive to glucosinolate breakdown products $(21,30,32,33)$. Results from field studies, however, have been inconsistent on population reduction and disease management. Inconsistencies in reducing microbial populations with brassica amendments may be attributed to the use of different brassica species, physical environments, and target organisms (41), soil temperature (8), and amount of crop residue incorporated (3). Smolinska (32) reported significant reductions of numbers of $F$. oxysporum chlamydospores with Brassica juncea cv. Malopolska and variable reductions with B. napus cv. Bolko. Takehara et al. (37) reported significant reductions in densities of $F$. oxysporum f. sp. spinaciae and $F$. oxysporum f. sp. lycopersici in soils amended with $B$. juncea. Amending soil with broccoli (B. oleracea) did not significantly reduce inocula of $F$. oxysporum $\mathrm{f}$. sp. asparagi and Fusarium spp. $(3,41)$.

Sclerotium rolfsii, Rhizoctonia spp., and Pythium spp. may be amenable to control with biofumigation. However, there are conflicting reports on the sensitivity of Rhizoctonia spp. and Pythium spp. to glucosinolate breakdown products. Sarwar et al. (30) reported that Rhizoctonia spp. was sensitive to isothiocyanates in vitro, whereas Pythium spp. generally was more tolerant. In contrast, Manici et al. (19) found that germination of $P$. irregulare oospores and subsequent mycelium growth was inhibited in sterilized soils treated with glucosinolate degradation products. Colonization by $R$. solani was inhibited by some glucosinolate degradation products although at glucosinolate rates higher than those required for $P$. irregulare. There has been minimal research on the effects of biofumigation on $S$. rolfsii. Gamliel and Stapleton (8) amended soil with cabbage (B. oleracea) residue and reported that the viability of $S$. rolfsii was reduced in nonheated soils but not as much as in heated soil.

A potential negative effect after amending soil with brassica residues is increased pathogen populations and decreased populations of beneficial organisms. In soil amended with B. napus seed meal, elevated populations of Pythium spp., relative to a nonamended control and 1,3dichloropropene $+17 \%$ chloropicrin (Telone C-17), were maintained throughout a 12- to 18-week observation period (5). Fluorescent pseudomonad populations were suppressed in amended soils. In contrast, a month after amending soils with $B$. juncea and B. napus, Smolinska (32) reported significantly higher populations of fungi and bacteria, including fluorescent pseudomonads, in amended soils compared with nonamended soils. However, populations of fluorescent pseudomonads do not always change in brassica-amended soil (31), suggesting that the type of brassica amendment and soil type may influence the effects on fluorescent pseudomonads. It is therefore important to monitor population densities of plant pathogens and beneficial soilborne microorganisms to better characterize the effects of amendments. 
The potential of using brassica crops for managing soilborne pathogens has been evaluated in the laboratory $(21,30,34,35)$ and in the field $(4,5,9,26,32,41)$ to assess fungistatic or fungicidal effects of glucosinolate breakdown products, i.e., isothiocyanates, on different fungi. In vitro tests are important, but field studies such as that by Gardiner et al. (9) suggest that the concentration of isothiocyanates in soil after brassica incorporation might be too low for effective pathogen control. Additional field studies are needed to relate isothiocyanate concentration in soil to population reductions in naturally infested soil and to disease management. Soil disinfestation with biofumigation may be improved by increasing the time isothiocyanates are present in soils. Isothiocyanates are volatile $(9,30)$, and preventing their escape from soil by laying polyethylene mulch, immediately after brassica incorporation, could possibly enhance pathogen management. The use of polyethylene mulch in combination with biofumigation has not been reported.

The first objective of this study was to determine the effect of incorporating two species of Brassica on densities of $F$. oxysporum, Pythium spp., $R$. solani, S. rolfsii, and fluorescent Pseudomonas spp. in soil. The second objective was to quantify glucosinolate breakdown products in the soil after brassica incorporation and determine if laying polyethylene mulch at incorporation time enhanced disinfestation compared with laying polyethylene mulch a month after incorporation, i.e., at planting time. The third objective was to evaluate the effectiveness of two brassica cover crops for control of damping-off and Fusarium wilt of watermelon compared with that obtained with methyl bromide. A preliminary report has been published (24).

\section{MATERIALS AND METHODS}

Field plot establishment. The experiment was conducted at the Clemson University Coastal Research and Education Center, Charleston, SC. The soil was Yonges loamy sand with a pH of 6.3 in 2004 and 6.1 in 2005. Previously, the field was planted with muskmelon (Cucumis melo L.) and watermelon in the spring of 2003 . To increase the inoculum density of $F$. oxysporum f. sp. niveum, watermelon cv. Black Diamond was direct-seeded 15 September 2003 and 11 and 25 August 2004 in all treatment plots. At the time of seeding, $280 \mathrm{~kg} / \mathrm{ha}$ ammonium sulfate 21 0-0 and $560 \mathrm{~kg} / \mathrm{ha} 10-10-10 \mathrm{~N}-\mathrm{P}-\mathrm{K}$ was applied in 2003 and 2004, respectively. In 2003, Black Diamond plants were mowed and the field was disked twice on 19 November. After seeding in 2004, emergence was poor due to excessive rainfall from Hurricane Charley, Tropical Depression Bonnie, and Tropical Storm Gaston. The field was not replanted and was disked twice.
The experimental design was a randomized complete block with six replications. Treatment plots measured 24.4 by $0.9 \mathrm{~m}$ with a 3-m fallow space between plots. Six treatments were evaluated: (i) nonamended control soil covered with black polyethylene mulch at transplanting; (ii) soil fumigated with methyl bromide at $448 \mathrm{~kg} / \mathrm{ha}$ and black polyethylene mulch applied a month before transplanting watermelon; (iii) canola (Brassica napus L. cv. Dwarf Essex) (Columbia Grain, Clarkston, WA) incorporated into soil and black polyethylene mulch applied 1 month later when watermelons were transplanted; (iv) canola incorporated into soil and soil covered immediately with black polyethylene mulch at incorporation time; (v) mustard (B. juncea (L.) Czern cv. Cutlass) (K. Downey, Saskatoon Research Center, Saskatoon, Canada) incorporated into soil and black polyethylene mulch applied 1 month later at transplanting; and (vi) mustard incorporated into soil and black polyethylene mulch applied immediately at incorporation time.

On 24 November 2003 and 3 November 2004, $672 \mathrm{~kg} / \mathrm{ha}$ 10-10-10 N-P-K fertilizer was applied followed by direct seeding of canola and mustard at 2.24 and $4.48 \mathrm{~kg} / \mathrm{ha}$, respectively (13), using a Brillion turfmaker junior seeder (Brillion Iron Works Inc., Brillion, WI). The field was watered as needed by overhead irrigation. In 2005, $672 \mathrm{~kg} / \mathrm{ha}$ ammonium sulfate mixed with 1 $\mathrm{kg} / \mathrm{ha}$ boron (Solubor) was applied 3 months after seeding (11).

Plant biomass. To determine the biomass of canola and mustard, plants were dug from two randomly chosen $0.25-\mathrm{m}^{2}$ areas per plot (9) on 15 March 2004 and 30 March 2005, approximately 1 week before incorporation each year. The plants were counted, washed, and oven-dried at $50^{\circ} \mathrm{C}$ for 1 week. The plants were then cut at the crown to separate roots and shoots, and dry weights of each were measured.

Quantifying glucosinolates. To quantify glucosinolate content in the canola and mustard crops, five additional plants were dug from each plot 1 week prior to incorporation, put into plastic bags, and held on ice in a cooler until transported to the laboratory. In 2004, roots and shoots were cut separately into small pieces, and two 5-g subsamples from each plot were frozen in liquid nitrogen before being freeze-dried. In 2005 , the plants were stored at $-80^{\circ} \mathrm{C}$ for 12 months before freeze drying. In both years, freeze-dried plant parts were ground using a Wiley mill equipped with a 1-mm mesh sieve. The powder was kept in a screw-cap test tube and stored at $5^{\circ} \mathrm{C}$ in a refrigerator until assayed for glucosinolates 2 weeks later.

Glucosinolates were extracted from freeze-dried root and shoot tissues (300 $\mathrm{mg}$ ) using the procedure described by Magrath et al. (18) with modifications employed by Kirkegaard and Sarwar (15). To quantify desulphoglucosinolates, 2-propenyl and benzyl glucosinolates were used as internal standards. Concentrations of other glucosinolates were determined using response factors for desulphoglucosinolates published by the European Economic Community (6). Desulphoglucosinolates were analyzed in a Hewlett Packard 1090 high pressure liquid chromatograph (Agilent Technologies, Wilmington, DE) equipped with a diode array detector set at $229 \mathrm{~nm}$ and Lichrosorb RP 18 column $(5 \mu \mathrm{m}, 150 \mathrm{~mm} \times 3.2 \mathrm{~mm}, \mathrm{Al}-$ tech, Deerfield, IL). The solvent system was water (A): acetonitrile (B) $(100 \%$ A for $5 \mathrm{~min}$, then increased $\% \mathrm{~B}$ to $35 \%$ over the next $25 \mathrm{~min}$, which was held $3 \mathrm{~min}$ and then increased to $100 \% \mathrm{~B}$ over $0.5 \mathrm{~min}$ and held for $5 \mathrm{~min}$, followed by reequilibration to $100 \%$ A for $5 \mathrm{~min}$ ). Peaks were identified by comparison to pure standard retention times. Forty-eight and 24 samples were analyzed in 2004 and 2005, i.e., one sample per replication and one sample from half of the replications, respectively. To calculate glucosinolate concentration incorporated per square meter, glucosinolate concentrations per gram were multiplied by biomass per square meter $(23,29)$.

Quantifying isothiocyanates in soil. Canola and mustard plants were mowed and then rototilled (Ferguson Tilrovator, Ferguson Mfg. Co., Suffolk, VA) $15 \mathrm{~cm}$ deep into the soil on 17 March 2004 and 5 April 2005. In 2004, 50\% of canola and $10 \%$ of mustard plants had flowered, whereas approximately $90 \%$ of canola and $50 \%$ of mustard plants had flowered in 2005. Most nonflowering plants had unopened flower buds.

After incorporation, soil samples were taken 0 to $15 \mathrm{~cm}$ deep using a $2.5-\mathrm{cm}$ diameter soil probe, 1 core per plot, at 6 time intervals: 0 and $6 \mathrm{~h}$, and 1, 2, 12, and 26 days after incorporation in 2004, and 0 and $6 \mathrm{~h}$, and 1, 2, 4, and 12 days in 2005 . Soil cores were placed in a 50-ml Pyrex centrifuge tube containing $5 \mathrm{ml}$ of $0.2 \mathrm{M}$ $\mathrm{CaCl}_{2}$ and $12 \mathrm{ml}$ of dichloromethane with $0.1 \%$ cyclohexane as an internal standard (9). A total of 216 samples (6 treatments $\times$ 6 replications $\times 6$ sampling times) collected in 2004 and 108 samples (6 treatments $\times 3$ replications $\times 6$ sampling times) collected in 2005 were analyzed. Fewer samples were analyzed from 2005 because isothiocyanates were not detected at the later sampling times in 2004. Gardiner's et al. (9) methods were used for extraction. Samples were analyzed on a Hewlett Packard 5890 gas chromatograph (GC) with a 5971A mass selective detector (MS) (Agilent Technologies) and DB5-MS column $(30 \mathrm{~m} \times 0.25 \mathrm{~mm}, 0.5 \mu \mathrm{m}$ film, Agilent Technologies). GC/MS operating conditions were: injector $250^{\circ} \mathrm{C}$, interface $300^{\circ} \mathrm{C}$, initial column temperature $70^{\circ} \mathrm{C}$ for $3 \mathrm{~min}$, then increased $6^{\circ} \mathrm{C} / \mathrm{min}$ to $240^{\circ} \mathrm{C}$, then $30^{\circ} \mathrm{C} / \mathrm{min}$ to $280^{\circ} \mathrm{C}$, which 
was held $1 \mathrm{~min}$. Helium was the carrier gas at $1 \mathrm{ml} / \mathrm{min}$; scan range $\mathrm{m} / \mathrm{z} 50$ to 425 . External standards used for quantification included allyl isothiocyanate (Lancaster Synthesis, Inc., Pelham, NH), N-propyl, phenyl, benzyl, methyl, 2-phenylethyl isothiocyanates and goitrin (oxazolidinethione) (Alfa Aesar, Ward Hill, MA).

Quantifying microorganisms in soil. To determine preincorporation population density of $F$. oxysporum, $R$. solani, Pythium spp., and $S$. rolfsii and population density of fluorescent pseudomonads, soil samples were taken on 9 March 2004 and 25 and 26 March 2005. Postincorporation population densities were assayed on 27 April 2004 and 18 April 2005. F. oxysporum was also quantified at the end of the season on 16 August 2005. Using a 2.5 -cm-diameter soil probe, 30 soil cores were taken to a depth of $15 \mathrm{~cm}$ from each plot. Soil cores from each plot were combined and thoroughly mixed before assaying for microorganisms. Microbial assays were conducted the same day, or soil was stored at $5^{\circ} \mathrm{C}$ for 1 to 2 days.

To estimate the population density of Pythium spp., $10 \mathrm{~g}$ of soil from each plot were added to $200 \mathrm{ml}$ of $0.3 \%$ water agar and shaken for $30 \mathrm{~s}$. Three aliquots $(0.5 \mathrm{ml}$ on each plate) were spread on plates of pimaricin-ampicillin-rifampicin-pentachloronitrobenzene (PCNB) medium prepared with pimaricin at $5 \mathrm{mg} / \mathrm{liter}\left(\mathrm{P}_{5} \mathrm{ARP}\right)(13)$. Plates were incubated at $20^{\circ} \mathrm{C}$ for $20 \mathrm{~h}$, and then adhering soil was washed away. Plates were reincubated at $20^{\circ} \mathrm{C}$, and large-sized colonies (ca. $>1 \mathrm{~cm}$ ) were counted at 36 to $48 \mathrm{~h}$ after plating. Randomly selected colonies were later identified to species level using morphological techniques, described later. Colony counts were expressed as colony forming units (CFU) per gram of soil dried for 24 $\mathrm{h}$ at $100^{\circ} \mathrm{C}$.

To estimate the population density of $R$. solani, $300 \mathrm{~g}$ of soil from each plot was wet-sieved through a \#18 mesh sieve (1$\mathrm{mm}$ pore opening) to recover organic matter (39). The organic matter was air-dried at 22 to $24^{\circ} \mathrm{C}$ overnight. Dried organic matter from each sample was placed in 10 small heaps of equivalent size on ethanolpotassium-nitrate agar, prepared with $2 \%$ ethanol and $8 \mathrm{mg} /$ liter prochloraz (38). The total numbers of heaps with and without colonies of $R$. solani growing from them were recorded after incubating 3 to 4 days in the dark at 23 to $25^{\circ} \mathrm{C}$. Hyphae of selected colonies were stained in situ with $3 \% \mathrm{KOH}$ and alkaline safranin $\mathrm{O}$ stain and examined at $\times 200$ to $\times 400$ to determine the number of nuclei per cell (2).

To estimate the population density of fluorescent Pseudomonas spp., $10 \mathrm{~g}$ of soil from each plot was added to $90 \mathrm{ml}$ of sterile distilled water and shaken for $30 \mathrm{~s}$. Further 10-fold dilutions were made, and three $0.1-\mathrm{ml}$ aliquots of $10^{-1}$ and $10^{-2}$ dilutions were spread on S-1 medium (10). S-1 plates were incubated in the dark at 23 to $25^{\circ} \mathrm{C}$ for 3 to 4 days, and colonies of fluorescent Pseudomonas spp. were counted under long-wave ultraviolet light. All colony counts were expressed as $\mathrm{CFU}$ per gram of soil dried for $24 \mathrm{~h}$ at $100^{\circ} \mathrm{C}$.

To estimate the population density of $S$. rolfsii, 300-g aliquots of soil from each plot were air-dried overnight in aluminum pans $(30 \times 24 \times 4 \mathrm{~cm})$ at ambient temperatures $\left(22\right.$ to $24^{\circ} \mathrm{C}$ ). Dried soil was spread evenly in pans and moistened with $75 \mathrm{ml}$ of $1.33 \%(\mathrm{vol} / \mathrm{vol})$ methanol (28). Aluminum pans then were put into large Ziploc plastic bags and incubated at $30^{\circ} \mathrm{C}, 3$ to 4 days. Germinated sclerotia were counted by closely examining the soil surface visually for discrete colonies of $S$. rolfsii.

To estimate the population density of $F$. oxysporum, $10 \mathrm{~g}$ of soil from each plot was added to $90 \mathrm{ml}$ of sterile distilled water and shaken for $1 \mathrm{~min}$. Further 10-fold dilutions were made, and three $0.1-\mathrm{ml}$ aliquots of $10^{-1}$ and $10^{-2}$ (an aliquot per plate) were spread on Komada's medium (16). The plates were held under diurnal light (16-h photoperiod) at ambient temperature (22 to $24^{\circ} \mathrm{C}$ ) for 4 to 5 days. Colony counts were expressed as CFU per gram of soil dried for $24 \mathrm{~h}$ at $100^{\circ} \mathrm{C}$.

Pythium identification. In 2005, 20 hyphal tips from colonies of Pythium spp. randomly selected from sampling time 1 soil dilution plates to represent all treatment plots were transferred to cornmeal agar (CMA). Nineteen Pythium isolates recovered from watermelon roots in 2005 also were transferred to CMA. Isolates were identified to species using a grassleaf blade culture technique (40). Freshly harvested St. Augustine grass blades (Stenotaphrum secundatum) were cut ca. 1 $\mathrm{cm}$ long, added to distilled water in a covered beaker, and boiled for $10 \mathrm{~min}(20,40)$. Six 1-cm plugs from the edge of 3-day-old cultures of Pythium spp. on CMA were transferred to a sterile petri dish with a 0.5 $\mathrm{cm}$ layer of sterile deionized water (1). Ten to 12 sterile grass blades were placed next to the agar plugs and incubated at room temperature with a 16-h photoperiod (20). At desired time intervals ( 2 to 4 days for asexual structures and 3 to 10 days for sexual structures) leaf samples were placed on a slide, stained with $0.05 \%$ trypan blue with lactophenol, and examined with a compound microscope at $\times 400$ and $\times 1,000$.

Watermelon damping-off and Fusarium wilt. A month after the incorporation of mustard and canola, seedless watermelon cv. Tri-X 313, susceptible to Fusarium wilt, was transplanted into single-row plots. Transplants were spaced $30 \mathrm{~cm}$ apart within rows. 'Black Diamond' seeded pollenizer plants were transplanted into rows between plots. Plots were watered and fertigated using drip irrigation. During the growing seasons, recommended preventative fungicides were applied to man- age foliar diseases. On 28 June to 13 July 2004 and 20 July to 5 August 2005, fruits were harvested from a $12-\mathrm{m}$ length in the middle of each plot and weighed.

The numbers of healthy, diseased, and dead plants in each plot were counted weekly until canopies of adjacent plants joined. To identify pathogens causing damping-off, all diseased watermelon plants (79 plants) were collected on 25 May 2005 from all treatments and washed under running tap water. Portions of necrotic lesions on stems and roots were cut into 5-mm pieces, surface-disinfested in $0.6 \% \mathrm{NaOCl}$ for $30 \mathrm{~s}$, rinsed in sterile distilled water, blotted dry, and placed on water agar amended with streptomycin $(100 \mathrm{mg} / \mathrm{liter})$ and on Komada's medium. Plates were incubated at ambient temperature $\left(22\right.$ to $\left.23^{\circ} \mathrm{C}\right)$ under $16-\mathrm{h}$ photoperiod, and recovered fungi were identified.

To rate the percentage of wilted foliage in each plot, plots were divided into quarters and disease severity assessments were made in each quarter plot on the canopy just before the first harvest and then on weekly intervals using a modified Horsfall-Barratt 15-point rating scale (14).

Pathogenicity and race tests for $F$. oxysporum f. sp. niveum. On 15 July 2004, four vines from symptomatic Tri-X 313 plants were collected from each treatment plot. The vines were cut into $1-\mathrm{cm}$ sections, disinfected in $0.6 \% \mathrm{NaOCl}$ for 1 min, rinsed in sterile distilled water for 1 min, and placed on Komada's media with five segments from one vine on each plate (four plates per plot). From these plates, 43 isolates of $F$. oxysporum were recovered. On 29 May and 16 June 2005, 36 F. oxysporum isolates were obtained from the wilting 2-month-old watermelon plants, isolated as previously described. Three agar plugs from 1-week-old single-spore $F$. oxysporum isolates grown on quarterstrength potato dextrose agar were placed in $50 \mathrm{ml}$ of potato dextrose broth in a 250$\mathrm{ml}$ flask and shaken at $150 \mathrm{rpm}$ at ambient temperature $\left(22\right.$ to $\left.24^{\circ} \mathrm{C}\right)$ for 4 days. Cultures were decanted through sterile cheesecloth in a sterile funnel into sterile $50-\mathrm{ml}$ centrifuge tubes, and the fungal mats were washed with 5 to $10 \mathrm{ml}$ of sterile distilled water to dislodge conidia. Culture filtrates were centrifuged at $1,398 \times g$ for $10 \mathrm{~min}$ to pellet spores, and spores were resuspended in $10 \mathrm{ml}$ of sterile distilled water. Spore concentration was determined by counting with a hemacytometer, and the concentration was adjusted to $10^{6} \mathrm{microconidia} / \mathrm{ml}$. Isolates with low concentrations of conidia were not used in pathogenicity and race tests. Pathogenicity tests were set up in a completely randomized experiment with five replications. A replication consisted of four seedlings in a 15-cm-diameter pot. Black Diamond was used for all pathogenicity tests.

Race tests were set up in a completely randomized experiment with three replica- 
tions. Isolates inciting wilt on $\geq 50 \%$ of $\mathrm{cv}$. Black Diamond plants were tested on the differential cultivars Black Diamond, Charleston Gray, and Calhoun Gray to identify the race of $F$. oxysporum $\mathrm{f}$. sp. niveum (7). In 2005, Allsweet was used in place of Calhoun Gray (42) because seed of Calhoun Gray was not available. Race determination experiments were conducted twice.

In both pathogenicity and race tests, watermelon was seeded in flats containing 1:1 $\mathrm{vol} / \mathrm{vol}$ sand:vermiculite and grown for 2 weeks. Seedlings were removed from flats, and their roots were washed under running tap water. To inoculate plants, roots were dipped into the conidia suspension for $10 \mathrm{~s}$ and transplanted into $15-\mathrm{cm}$-diameter pots containing a 4:1:1 (vol/vol/vol) mix of sand:peat:vermiculite (7). Roots of an equal number of plants were dipped in sterile distilled water as the negative control. Two isolates of $F$. oxysporum f. sp. niveum race 2, FON 997 and FON 998 (isolated from watermelon cv. Stars and Stripes, Colleton County, SC), were included as positive controls. Wilted plants were counted weekly starting 2 weeks after inoculation for a total of 6 weeks. Thirtytwo symptomatic plants (representing all differential cultivars), from both pathogenicity and race determination experiments, were selected randomly, and roots or hypocotyls cultured on quarter-strength potato dextrose agar to confirm presence of F. oxysporum f. sp. niveum. Temperature was set at $28^{\circ} \mathrm{C}$ in the greenhouse during experiments, but ranged from 16 to $40^{\circ} \mathrm{C}$ over the course of the experiment.

Statistical analysis. Analysis of variance was performed with PROC GLM of SAS (SAS Institute, Cary, NC; release 8.2 for personal computers). All data sets were checked for normality, and Hartley's test for equality of variance was calculated
(17). CFUs of $F$. oxysporum, Pythium spp., and fluorescent Pseudomonas spp. were transformed to logarithm values. Preplanned comparisons using single-degreeof-freedom contrast statements were used to compare effects of treatment on microbial populations. For pretreatment microbial densities, means of similar treatments (i.e., two nonplanted, two canola, and two mustard treatments) were pooled before comparisons were made. Treatment means for final incidence of damping-off, Fusarium wilt severity, and yield were compared using Fisher's Protected LSD $(P=$ 0.05). For glucosinolate concentrations, means were pooled within species and standard errors calculated. Single-degreeof-freedom contrast statements were used to compare total glucosinolate concentrations.

\section{RESULTS}

Glucosinolate content. In 2004 and 2005, the average mustard biomass ( $\mathrm{kg} / \mathrm{ha})$ at incorporation was 3,984 and 8,489 (294 and 789 std errors, respectively), and that of canola was 4,754 and 9,659 (448 and 968 std errors, respectively). Total glucosinolate concentration incorporated per square meter was significantly higher for mustard than for canola in both years $(P<$ 0.0001 ) (Table 1). Total glucosinolate concentration for both species was higher in 2005 than in $2004(P<0.0001)$.

In 2004 and 2005, five glucosinolates (2-phenylethyl, 2-hydroxy-3-butenyl, 3butenyl, 2-propenyl, and epigoitrin) were identified in mustard, and three glucosinolates (2-phenylethyl, benzyl, and 3butenyl) were identified in canola (Table 1). Epigoitrin, 2-hydroxy-3-butenyl, and 2propenyl were only detected in mustard, whereas benzyl was only detected in canola. Quantitatively, root tissue of both cultivars had significantly higher concen- trations of 2-phenylethyl than shoot tissue $(P<0.0001)$ (Table 1$)$. The predominant glucosinolate in the roots of both canola and mustard was 2-phenylethyl. Shoots contained low concentrations of several glucosinolates, but no one glucosinolate predominated. Within species, shoots and roots contained the same glucosinolates.

Isothiocyanate detection in soil. Isothiocyanates were not detected in soil samples taken at the zero sampling time after plant tissue incorporation either year. In 2004, 2-phenylethyl ITC was detected in 10 of 144 samples from brassicaamended soils with equal numbers of positive samples from covered or uncovered plots. In 2004, 2-phenylethyl ITC was detected in 6 of 24 samples from amended soil taken $6 \mathrm{~h}$ after incorporation (4 canola- and 2 mustard-amended soils); 2 of 24 samples from amended soil taken 1 day after incorporation (both from mustardamended soils); 1 of 24 samples from amended soil taken 2 days after incorporation (mustard-amended soil); and 1 of 24 samples from amended soil taken 12 days after incorporation (canola-amended soil). Benzyl ITC was detected in 2 of the 144 samples taken in 2004 in samples taken $6 \mathrm{~h}$ after incorporation in canola-amended soils covered with polyethylene mulch.

Of the 72 samples obtained from amended soil in 2005, 2-phenylethyl and benzyl ITC were detected in 4 and 1 samples, respectively. No ITCs were detected at incorporation time. 2-Phenylethyl ITC was detected in 2 of 12 amended soil samples taken $6 \mathrm{~h}$ after incorporation, and in 2 of 12 amended soil samples taken 1 day after incorporation (all from mustardamended soils). Benzyl ITC was only detected in 1 sample from canola-amended soil 12 days after incorporation in 2005.

Microbial populations. In 2004 and 2005, prior to incorporating brassica or

Table 1. Concentration ( $\mu \mathrm{mol} / \mathrm{g}$ ) of glucosinolates in roots and shoots of Brassica napus cv. Dwarf Essex (canola) and B. juncea cv. Cutlass (mustard) prior to incorporation into the soil and total concentrations per area $\left(\mu \mathrm{mol} / \mathrm{m}^{2}\right)$

\begin{tabular}{|c|c|c|c|c|c|c|}
\hline \multirow{2}{*}{$\begin{array}{l}\text { Year } \\
\quad \text { Glucosinolate }^{x}\end{array}$} & \multicolumn{2}{|c|}{ B. napus } & \multicolumn{2}{|c|}{ B. juncea } & \multicolumn{2}{|c|}{ Total $^{w}$} \\
\hline & Root & Shoot & Root & Shoot & B. napus & B. juncea \\
\hline \multicolumn{7}{|l|}{2004} \\
\hline Epigoitrin & ndy & nd & $0.06(0.01)^{\mathrm{z}}$ & $0.02(0.01)$ & nd & $9.8(4.2)$ \\
\hline 2-Hydroxy-3-butenyl (Progoitrin) & nd & nd & $2.87(0.50)$ & $1.61(0.26)$ & nd & $654.7(80.7)$ \\
\hline 3-Butenyl (Gluconapin) & $0.05(0.01)$ & $0.07(0.02)$ & $0.46(0.08)$ & $1.12(0.16)$ & $30.7(6.5)$ & $354.5(50.1)$ \\
\hline 2-Phenylethyl (Gluconasturtiin) & $4.53(0.41)$ & $0.09(0.02)$ & $21.68(1.89)$ & $0.48(0.14)$ & $771.8(78.2)$ & $1,608.6(142.0)$ \\
\hline Benzyl (Glucotropaeolin) & $0.68(0.08)$ & $0.18(0.03)$ & nd & nd & $169.3(13.5)$ & nd \\
\hline 2-Propenyl (Sinigrin) & nd & nd & $0.24(0.10)$ & $0.26(0.08)$ & nd & $91.2(30.2)$ \\
\hline Total & $5.26(0.42)$ & $0.34(0.03)$ & $25.31(2.94)$ & $3.04(0.48)$ & $971.8(74.2)$ & $2,718.8(217.8)$ \\
\hline \multicolumn{7}{|l|}{2005} \\
\hline Epigoitrin & nd & nd & $0.05(0.01)$ & nd & nd & $10.8(3.6)$ \\
\hline 2-Hydroxy-3-butenyl (Progoitrin) & nd & nd & $1.49(0.36)$ & $2.04(0.41)$ & nd & $1,435.7(156.4)$ \\
\hline 3-Butenyl (Gluconapin) & $0.12(0.02)$ & $0.07(0.02)$ & $0.61(0.16)$ & $2.83(0.64)$ & $71.1(9.1)$ & $1,676.9(210.2)$ \\
\hline 2-Phenylethyl (Gluconasturtiin) & $6.22(0.26)$ & $0.14(0.01)$ & $18.30(2.20)$ & $0.09(0.01)$ & $1,379.9(103.4)$ & $4,001.9(672.7)$ \\
\hline Benzyl (Glucotropaeolin) & $0.75(0.12)$ & $0.11(0.01)$ & nd & nd & $227.8(30.5)$ & nd \\
\hline 2-Propenyl (Sinigrin) & nd & nd & $0.31(0.12)$ & $0.22(0.08)$ & nd & $187.1(28.6)$ \\
\hline Total & $7.09(1.23)$ & $0.32(0.08)$ & $20.67(1.53)$ & $5.18(0.21)$ & $1,678.8(124.3)$ & $7,311.5(801.4)$ \\
\hline
\end{tabular}

${ }^{\mathrm{w}}$ Total glucosinolate concentrations were calculated by multiplying glucosinolate concentrations per gram by biomass per meter squared.

${ }^{x}$ Glucosinolates were identified using standards and their elution times on high pressure liquid chromatography.

y None detected.

${ }^{\mathrm{z}}$ One standard error of the mean. 
applying methyl bromide, population densities of $F$. oxysporum were not significantly different $(P>0.05)$ between planted and nonplanted treatments or between planted treatments (Figs. 1 and 2). Posttreatment in 2004, F. oxysporum densities were significantly lower in methyl bromide-treated soils compared with densities in all amended soils $(P \leq 0.01)$ except compared with densities in mustard + mulch soils $(P=0.07)$ (Fig. 1). Population densities of $F$. oxysporum were significantly higher in all amended soils $(P \leq$ 0.01) compared with those in control soils, except for those in mustard + mulch soils $(P=0.1)$ (Fig. 1). Posttreatment in 2004, $F$. oxysporum densities were significantly lower $(P=0.03)$ in mustard + mulch soils compared with those in mustard no mulch soils (Fig. 1). There were no significant differences in $F$. oxysporum population densities among the other amended soils in 2004.

In 2005,3 weeks after treatments were applied, $F$. oxysporum densities in methyl bromide-treated soil were significantly lower than those in control soil $(P=0.03)$ and in all the amended treatments $(P \leq$ 0.004) (Fig. 2). F. oxysporum populations generally were not significantly higher in amended soils compared with control soils except in canola no mulch soils $(P<$ 0.003) (Fig. 2). After treatment in 2005, F. oxysporum densities were significantly higher in canola no mulch soils compared with densities in canola + mulch soils $(P=$ 0.04) (Fig. 2). F. oxysporum densities in canola no mulch soils were significantly higher $(P=0.04)$ than those in mustardamended soils (Fig. 2). F. oxysporum densities did not differ among the other amended treatments at the second sampling (Fig. 2).

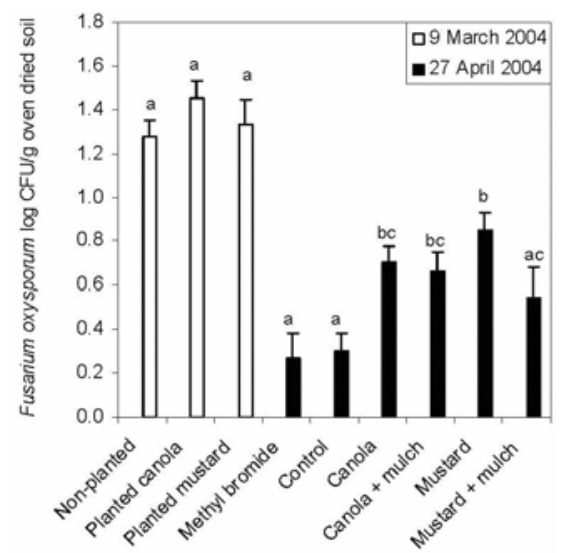

Fig. 1. Population densities of Fusarium oxysporum before and after treatment in 2004. Polyethylene mulch was applied immediately in the amended treatments + mulch and in the methyl bromide treatment, whereas mulch was applied a month later in the other treatments. Within sampling dates, values with the same letters do not differ significantly $(P \leq 0.05)$. Error bars indicate one standard error of the mean.
Compared to densities at the second sampling, $F$. oxysporum population increased significantly $(P<0.0001)$ by the third sampling in methyl bromide-treated soils (Fig. 2). At the end of the season in August 2005, F. oxysporum densities were significantly higher in all the treated plots compared with the nontreated control $(P \leq$ 0.01). At the third sampling in 2005, $F$. oxysporum densities were not significantly different $(P>0.05)$ among the five treated soils (Fig. 2).

In 2004, prior to incorporating brassica or applying methyl bromide, Pythium spp. population densities were significantly higher $(P=0.03)$ in soils cropped to mustard than in nonplanted soils (Fig. 3). Pythium spp. identified from soil collected in 2005 were $P$. irregulare (14 isolates) and $P$. spinosum (5 isolates). One isolate could not be identified.

Posttreatment in 2004, Pythium spp. population densities were significantly lower in methyl bromide-treated soils compared with those in control soils $(P=$ $0.04)$ and in all biofumigation treatments $(P<0.02)$ (Fig. 3). Pythium spp. population densities were not significantly different among amended soils or between control and brassica-amended soils $(P>0.05)$ (Fig. 3).

In 2005, before brassicas were incorporated, populations of Pythium spp. were not significantly different between those in soils cropped to canola and mustard (Fig. 4). However, population densities of $P y$ thium spp. were significantly higher in planted soils $(P \leq 0.02)$ compared with nonplanted soils (Fig. 4).

Posttreatment in 2005, Pythium spp. densities in soils treated with methyl bromide were significantly lower than those in control soils and in all amended soils $(P \leq$ 0.01) (Fig. 4). Compared to the control,

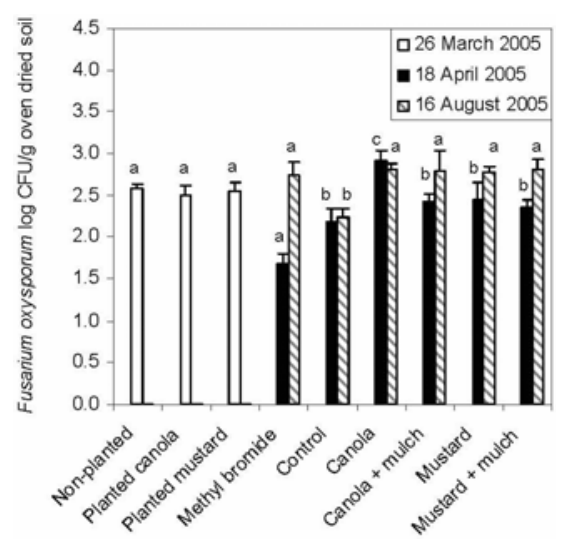

Fig. 2. Population densities of Fusarium oxysporum before and 3 weeks after treatment and at the end of the season in 2005. Polyethylene mulch was applied immediately in the amended treatments + mulch and in the methyl bromide treatment, whereas mulch was applied a month later in the other treatments. Within sampling dates, values with the same letters do not differ significantly $(P \leq 0.05)$. Error bars indicate one standard error of the mean.
Pythium spp. densities were significantly higher in canola no mulch soils $(P=0.01)$ and in mustard no mulch soil $(P=0.03)$. Pythium spp. densities were significantly lower in mustard + mulch soils $(P=0.02)$ compared with those in mustard no mulch soils (Fig. 4) but not significantly different $(P>0.05)$ compared to canola + mulch soils (Fig. 4).

In 2004 and 2005, before brassicas were incorporated or methyl bromide was applied, $R$. solani population densities were not significantly different $(P>0.05)$ between planted and nonplanted treatments or between mustard and canola (data not shown). Posttreatment in 2004 and 2005, population densities of $R$. solani were not significantly different $(P>0.05)$ among treatments (data not shown). Mean per-

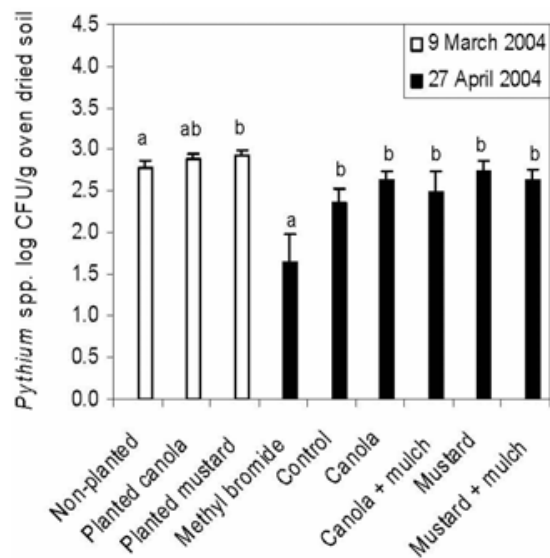

Fig. 3. Population densities of Pythium spp before and after treatment in 2004. Polyethylene mulch was applied immediately in the amended treatments + mulch and in the methyl bromide treatment, whereas mulch was applied a month later in the other treatments. Within sampling dates, values with the same letters do not differ significantly $(P \leq 0.05)$. Error bars indicate one standard error of the mean.

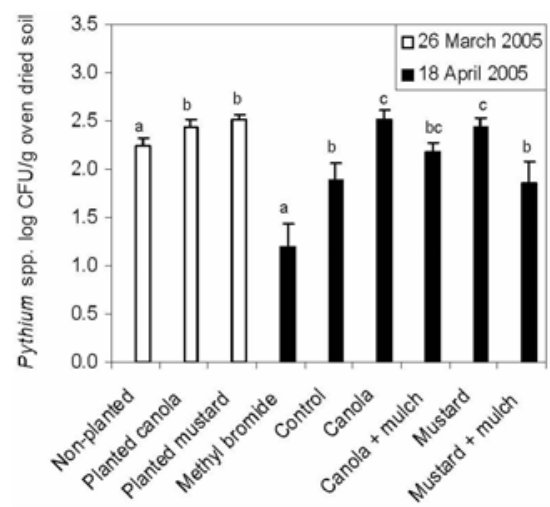

Fig. 4. Population densities of Pythium spp before and after treatment in 2005. Polyethylene mulch was applied immediately in the amended treatments + mulch and in the methyl bromide treatment, whereas mulch was applied a month later in the other treatments. Within sampling dates, values with the same letters do not differ significantly $(P \leq 0.05)$. Error bars indicate one standard error of the mean. 
centage of organic matter colonized by $R$. solani was $42 \%$.

In 2004, before treatments were applied, $S$. rolfsii population densities were significantly higher in mustard-cropped soils (6 CFU/300 g soil $)(P=0.002)$ and in canolacropped soils $(4.3 \mathrm{CFU} / 300 \mathrm{~g}$ soil $)(P=$ $0.05)$ compared with nonplanted soils (1.7 CFU/300 g soil). However, S. rolfsii densities were not significantly different $(P>$ 0.05 ) between canola and mustard. After treatments were applied in 2004, S. rolfsii population densities did not differ significantly among treatments.

In 2005, before treatments were applied, population densities of $S$. rolfsii were not significantly different $(P>0.05)$ among treatments. Posttreatment in 2005, the population density of $S$. rolfsii decreased significantly only in soils treated with methyl bromide $(P=0.01)$. $S$. rolfsii population densities in the mustard + mulch soils (1 CFU/300 g soil) were significantly lower than in mustard no mulch soils (3 CFU/300 g soil) $(P=0.04)$. However, no treatments differed from either the methyl bromide-treated or control soils at the second sampling.

In 2004, before and after treatments were applied, there were no significant differences $(P>0.05)$ in densities of fluorescent Pseudomonas spp. among treatments (data not shown). In 2005, before treatments were applied, population densities of fluorescent Pseudomonas spp. were not significantly different in soils planted with brassica or not planted (Fig. 5). After treatments were applied in 2005, populations of fluorescent Pseudomonas spp. were significantly higher in canola no mulch and mustard no mulch soils $(P=$ 0.0002 for canola and $P=0.03$ for mustard) compared with methyl bromidetreated soils (Fig. 5). Compared to control

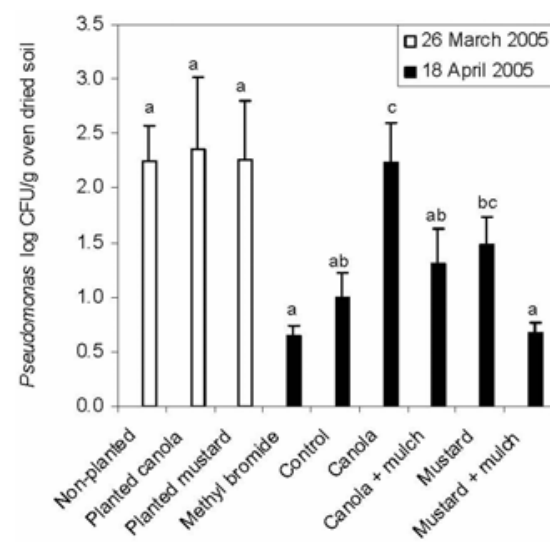

Fig. 5. Population densities of fluorescent Pseudomonas spp. before and after treatment in 2005. Polyethylene mulch was applied immediately in the amended treatments + mulch and in the methyl bromide treatment, whereas mulch was applied a month later in the other treatments. Within sampling dates, values with the same letters do not differ significantly $(P \leq$ $0.05)$. Error bars indicate one standard error of the mean. soils, populations of fluorescent pseudomonads were significantly higher only in canola no mulch soils $(P=0.002)$. Fluorescent pseudomonad populations were significantly higher in brassica no mulch soils compared with populations in brassica + mulch soils $(P=0.02$ for canola and $P=0.04$ for mustard) (Fig. 5). Population densities of fluorescent pseudomonads did not differ significantly among the other amendment treatments (Fig. 5).

Disease and yield. In 2005, pathogens were isolated from 79 Tri-X 313 plants exhibiting damping-off symptoms. $F$. oxysporum was isolated from 70 plants, $P y$ thium spp. were isolated from 45 plants, and $R$. solani was isolated from five plants. Forty-two damped-off plants had both $F$. oxysporum and Pythium spp. Of 19 isolates of Pythium spp. identified, 16 isolates were $P$. aphanidermatum, one isolate was $P$. spinosum, and one isolate was $P$. myriotylum. The remaining Pythium spp. isolate could not be identified.

In 2004, incidence of damping-off did not differ between brassica-amended plots and the control or methyl bromide treatments (Table 2). The incidence of damping-off was lower in canola + mulch soil than in mustard + mulch soil (Table 2 ). In 2005 , incidence of damping-off in canolaamended soil was significantly lower than in the nonamended control (Table 2). There were no significant differences in incidences of damping-off among brassicaamended soils or between amended soils and methyl bromide-treated soil.

There were no significant differences in wilt severity among treatments in 2004 (Table 2). In 2005, wilt severity was significantly lower in canola no mulch soil than in mustard no mulch soil (Table 2). Wilt severity also was significantly lower in canola no mulch soils than in methyl bromide-treated soil (Table 2).

In 2004, canola + mulch treatment had a lower weight of melons compared with mustard no mulch soils (Table 2). In 2005, yields were slightly more variable among treatments than in 2004, but were not significantly different among treatments (Table 2).

$F$. oxysporum pathogenicity and race determination of $\boldsymbol{F}$. oxysporum f. sp. niveum. In 2004, 24 of the $43 F$. oxysporum isolates recovered from Tri-X 313 vines produced enough conidia to be screened for pathogenicity and race. Of the 24 , seven isolates were found to induce 50 to $100 \%$ wilting on cv. Black Diamond. All pathogenic isolates were from brassica-amended treatment plots. These seven $F$. oxysporum f. sp. niveum isolates were then screened to determine race using differential cultivars (Black Diamond, Charleston Gray, and Calhoun Gray). Four isolates induced a mean wilt of $<15 \%$ on Charleston Gray and Calhoun Gray and were identified as race 0 (42). Two isolates induced a mean wilt of 18 to $45 \%$ on Charleston Gray and Calhoun Gray and were identified as race 1 . One isolate induced a mean wilt of $>70 \%$ on all three cultivars and was identified as race 2 .

In 2005,35 out of the $36 F$. oxysporum isolates recovered from 2-month-old Tri-X 313 plants ( 1 month after transplanting) from both the vines and crowns were screened for pathogenicity and race. Of these, six isolates induced 50 to $100 \%$ wilt on Black Diamond. When screened against race differential cultivars (Black Diamond, Charleston Gray, and Allsweet), five isolates induced a mean wilt incidence of 70 to $90 \%$ over the three cultivars and were identified as race 2 . One isolate induced a

Table 2. Effects of incorporating Brassica napus cv. Dwarf Essex (canola) and B. juncea cv. Cutlass (mustard) on incidence of watermelon damping-off, Fusarium wilt severity, and yield

\begin{tabular}{lccc}
\hline $\begin{array}{l}\text { Year } \\
\text { Treatment }\end{array}$ & $\begin{array}{c}\text { Damping-off } \\
\text { incidence }^{\mathbf{u}}\end{array}$ & $\begin{array}{c}\text { Wilted and dead } \\
\text { canopy }^{\mathbf{v}} \mathbf{( \% )}\end{array}$ & $\begin{array}{c}\text { Yield } \\
(\mathbf{k g} / \mathbf{h a})\end{array}$ \\
\hline 2004 & & & \\
Methyl bromide & $\mathrm{w}$ & $28 \mathrm{a}$ & $13,537 \mathrm{ab}$ \\
Control & $10.7 \mathrm{ab}^{\mathrm{x}}$ & $23 \mathrm{a}$ & $15,506 \mathrm{ab}$ \\
Canola $^{\mathrm{y}}$ & $11.3 \mathrm{ab}$ & $23 \mathrm{a}$ & $14,379 \mathrm{ab}$ \\
Canola + mulch $^{\mathrm{z}}$ & $8.3 \mathrm{ab}$ & $18 \mathrm{a}$ & $13,158 \mathrm{~b}$ \\
Mustard $_{\text {Mustard }+ \text { mulch }^{\mathrm{z}}}$ & $7.7 \mathrm{~b}$ & $23 \mathrm{a}$ & $18,192 \mathrm{a}$ \\
LSD $(P<0.05)$ & $12.5 \mathrm{ab}$ & $22 \mathrm{a}$ & $14,589 \mathrm{ab}$ \\
2005 & $17.8 \mathrm{a}$ & 12 & 4,758 \\
Methyl bromide & 9.6 & $46 \mathrm{a}$ & $9,432 \mathrm{a}$ \\
Control & $30 \mathrm{ab}$ & $40 \mathrm{ab}$ & $8,713 \mathrm{a}$ \\
Canola & $52 \mathrm{a}$ & $18 \mathrm{~b}$ & $10,906 \mathrm{a}$ \\
Canola + mulch $^{\mathrm{z}}$ & $23 \mathrm{~b}$ & $37 \mathrm{ab}$ & $12,430 \mathrm{a}$ \\
Mustard & $24 \mathrm{~b}$ & $50 \mathrm{a}$ & $8,208 \mathrm{a}$ \\
Mustard + mulch $^{\mathrm{z}}$ & $43 \mathrm{ab}$ & $28 \mathrm{ab}$ & $7,152 \mathrm{a}$ \\
LSD $\left.^{\mathrm{y}}<0.05\right)$ & $28 \mathrm{ab}$ & 22 & 7,654 \\
\hline
\end{tabular}

u Plants were examined weekly for 4 to 5 weeks after transplanting for damping-off.

${ }^{\mathrm{v}}$ Fusarium wilt severity was rated as percent wilted foliage.

${ }^{\text {w }}$ Methyl bromide was applied at $448 \mathrm{~kg} / \mathrm{ha}$ about a month before transplanting watermelon.

${ }^{x}$ Means within a column with the same letter are not significantly different, Fisher's protected least significant difference $(P<0.05)$.

y Black polyethylene mulch applied a month after incorporation.

z Black polyethylene mulch was applied immediately after plants were incorporated. 
mean wilt incidence of $60 \%$ over the three cultivars and was identified as race 1 . Pathogenic races were obtained from the following treatments: two race 2 isolates from the control treatment, two race 2 isolates from brassica-amended treatments, one race 2 isolate from the methyl bromide treatment, and one race 1 isolate from brassica-amended treatment.

\section{DISCUSSION}

In our 2-year study in South Carolina, biofumigation was not effective at reducing populations of soilborne microorganisms. After incorporation of brassica plant material, microbial population densities in brassica-amended soils covered with mulch immediately or 1 month later were not significantly lower than those in control soils. In some cases, population densities of F. oxysporum and Pythium spp. in amended soils were significantly higher than those in control soils. Field studies with biofumigation not combined with another management method have shown inconsistent results when pathogen populations were measured. For example, after amending soil with various species of Brassica, significant reductions in populations of F. oxysporum, Verticillium dahliae, and Phytophthora cinnamomi have been observed $(26,32,36)$. In contrast, amending soil with broccoli (B. oleracea L.) did not significantly reduce inocula of $F$. oxysporum f. sp. asparagi, $R$. solani, and $V$. dahliae (3), and Fusarium spp. (41).

Laying polyethylene mulch immediately after brassica incorporation did not improve biofumigation. Since we detected isothiocyanates erratically among amended soils, the production of volatile fungitoxic chemicals may not have been high enough and therefore covering soil with polyethylene mulch did not improve disinfestation or disease management.

Disease control using biofumigation has been inconsistent, possibly due to several factors. Success in reducing disease with brassica amendment alone has been reported $(5,36)$, but there also are reports of lack of disease control $(3,41)$. In our study, damping-off incidence in canola-amended soils was significantly lower in 2005 compared with nontreated control soils. The amount of disease reduction in canolaamended soils could be a result of the higher plant biomass incorporated in 2005 compared with that in 2004. Although glucosinolate production per unit was higher for mustard than for canola, lower damping-off incidence was observed in canola-amended soils. This might suggest that an additional mechanism enhanced disease reduction and not just glucosinolate hydrolysis to isothiocyanates. Some researchers have suggested additional mechanisms of pathogen and disease control when soil is amended with brassicas, such as the ensuing anaerobic conditions $(3,37)$ and a nitrification effect $(5)$.
Fusarium wilt of watermelon generally was not controlled by amending soil with brassicas. F. oxysporum population density was lower in all treatments in 2004 compared with that in 2005. With the increase in population density in 2005 , wilt severity also increased in some treatments. In both years, the lowest wilt severity was in canola-amended soils, but it is unclear if this represented a trend toward disease suppression in this treatment.

Glucosinolate production per unit area has been used to assess the biofumigation potential of brassicaceous plants $(23,29)$. Higher concentrations of glucosinolates are desirable because, upon hydrolysis, they can yield higher concentrations of isothiocyanates, which have been shown to be fungitoxic or fungistatic. In 2004 and 2005, glucosinolate concentrations $(\mu \mathrm{mol} / \mathrm{g}$ ) for mustard and canola were similar to each other, but the amount of glucosinolate incorporated per unit area was higher in 2005 than in 2004 because of higher biomass in 2005. Glucosinolate production per square meter was estimated to be 2.8 and 4.4 times higher for mustard than for canola in 2004 and 2005, respectively.

In a recent multistate biofumigation study in the southeastern United States, Norsworthy et al. (25) reported that glucosinolate production from a mixture of spring-seeded B. juncea and Sinapsis alba was $8,600,12,000$, and $26,000 \mu \mathrm{mol} / \mathrm{m}^{2}$ in Arkansas, South Carolina, and Oklahoma, respectively. In our study with fall-seeded brassicas, we estimated total glucosinolate production in 2004 and 2005 was 970 and $1,680 \mu \mathrm{mol} / \mathrm{m}^{2}$ for canola and 2,720 and $7,310 \mu \mathrm{mol} / \mathrm{m}^{2}$ for mustard. Differences in glucosinolate production per unit area between the two studies may be attributed to biomass differences. Our seeding rate was $4 \mathrm{~kg} / \mathrm{ha}$, while Norsworthy et al. (25) used $19 \mathrm{~kg} / \mathrm{ha}$. Other factors such as environmental conditions, season of growth, and differences in species and cultivars, also affect glucosinolate content. Sarwar and Kirkegaard (29) reported that glucosinolate concentrations varied significantly with environment ( 3 to 10 times). When comparing fall-to-spring seeded brassicas, higher glucosinolate concentrations were found in spring-seeded brassicas. Implications of different concentrations of glucosinolates in fall- versus spring-seeded brassicas, such as the efficiency of conversion to ITCs, on management of soilborne fungi have not been examined.

The predominant glucosinolate in root tissue of both canola and mustard was 2phenylethyl, as reported previously $(9,15,25)$. Similarly, 2-phenylethyl ITC was the predominant ITC detected in soil. When Gardiner et al. (9) sampled soil after incorporating B. napus cv. Dwarf Essex, 2phenylethyl ITC also was the most abundant ITC; however, the concentration of most degradation compounds peaked $30 \mathrm{~h}$ after incorporation or a little later and de- creased erratically to 20 days after incorporation, after which time they were not detectable. In our experiment, after plants were incorporated into the soil, two isothiocyanates, 2-phenylethyl and benzyl, were detected in 2004. However, detection was not consistent among replications within the amended treatments, and no isothiocyanates were detected more than 12 days after incorporation. In 2005, plant biomass was increased with the aim to increase the amount of glucosinolate incorporated per unit area and, therefore, ITC detection and residence time in the soil. However, results for isothiocyanate detection in 2005 were similar to those observed in 2004. Thus, ITC concentration in soil is determined by factors in addition to the biomass of brassica crops incorporated.

Methods of incorporating brassicaceous plant material might affect the efficacy of biofumigation. Methods of incorporation include mowing and rototilling cover crops $(9,25)$, amending soil with milled plant material $(5,22,27)$, or placing crop debris on the soil surface and rototilling $(4,26,41)$. Coelho et al. (4) suggested that incorporating relatively large cabbage fragments may have led to uneven distribution of the amendment in the soil profile. In the present study, we observed shoot and root pieces that were not broken down into smaller fragments after both mowing and rototilling. This may be one reason for the low concentration of isothiocyanates detected in soil.

Soil temperature is another important factor in isothiocyanate formation (8). Gamliel and Stapleton (8) amended soil with cabbage residue and analyzed profiles of volatiles in the headspace. They reported that the concentrations of volatiles, which increased with an increase in soil temperature, were higher in heated, amended soils than in nonheated amended soil. Viability of $P$. ultimum and $S$. rolfsii were not affected in the nonsolarized soil, either nonamended or amended with cabbage residue (8). When plants were incorporated in March 2004 and April 2005 in our study, mean soil temperatures $5 \mathrm{~cm}$ deep were 19 and $18^{\circ} \mathrm{C}$, respectively, which might not have been warm enough to favor ITC production. However, biofumigation during warmer months or combined with soil solarization has not always made it more efficacious. Pinkerton et al. (26) found that amending soil with rape ( $B$. napus) alone during the summer in Oregon did not reduce Agrobacterium spp. populations. When rape was combined with solarization, better control was achieved over nonamended soils but not significantly better than solarized soils alone (26). In Florida, amending soil with cabbage did not improve the efficacy of solarization on survival of Phytophthora spp. (4).

Potential negative effects of biofumigation have been reported. Cohen et al. (5) 
amended soil with B. napus seed meal and observed increased population densities of Pythium spp., but numbers of fluorescent pseudomonads, a beneficial bacterium, were suppressed. We observed significantly higher populations of Pythium spp. before incorporation in canola-planted soils in 2004, and in both canola- and mustard-planted soils in 2005, than in fallow control plots. After incorporation in 2005 , populations of Pythium spp. increased in some amended soils while the end-of-theseason population densities of $F$. oxysporum were significantly higher in all amended soils compared with nontreated control soils. In our study, fluorescent pseudomonads were not suppressed by amending soil with brassicas.

Under spring conditions in the coastal southeastern United States, biofumigation does not appear to be an effective management tool for soilborne pathogens in watermelon production. Further research is needed, such as combination treatments with other management options or increasing the amount of brassica biomass incorporated, to make it more efficacious against damping-off and Fusarium wilt of watermelon for growers who seek a nonchemical alternative to fumigation.

\section{ACKNOWLEDGMENTS}

This material is based upon work supported by the CSREES/USDA under project numbers SC1700146 and 2003-34287-13481, and Southern Region SARE Graduate Student Project GS04-034. Technical contribution no. 5338 of the Clemson University Experiment Station. We thank V. DuBose, W. May, III, J. Cantrell, J. Howell, P. McLaughlin, and F. Harper for technical assistance.

\section{LITERATURE CITED}

1. Abad, Z. G., Shew, H. D., and Lucas, L. T. 1994. Characterization and pathogenicity of Pythium species isolated from turfgrass with symptoms of root and crown rot in North Carolina. Phytopathology 84:913-921.

2. Bandoni, R. J. 1979. Safranin as a rapid nuclear stain for fungi. Mycologia 71:873-874.

3. Blok, W. J., Lamers, J. G., Termorshuizen, A. J., and Bollen, G. J. 2000. Control of soilborne plant pathogens by incorporating fresh organic amendments followed by tarping. Phytopathology 90:253-259.

4. Coelho, L., Chellemi, D. O., and Mitchell, D. J. 1999. Efficacy of solarization and cabbage amendment for the control of Phytophthora spp. in North Florida. Plant Dis. 83:293-299.

5. Cohen, M. F., Yamasaki, H., and Mazzola, M. 2005. Brassica napus seed meal soil amendment modifies microbial community structure, nitric oxide production and incidence of Rhizoctonia root rot. Soil Biol. Biochem. 37:1215-1227.

6. EEC Regulation No. 1864/90. Enclosure VIII. Offic. J. Eur. Commun. L170:27-34.

7. Egel, D. S., Harikrishnan, R., and Martyn, R. 2004. Fusarium oxysporum $\mathrm{f}$. sp. niveum race 2 of watermelon in Indiana. (Abstr.) Phytopathology 94:S27.

8. Gamliel, A., and Stapleton, J. J. 1993. Characterization of antifungal volatile compounds evolved from solarized soil amended with cabbage residues. Phytopathology 83:899-905.
9. Gardiner, J. B., Morra, M. J., Eberlein, C. V., Brown, P. D., and Borek, V. 1999. Allelochemicals released in soil following incorporation of rapeseed (Brassica napus) green manures. J. Agric. Food Chem. 47:3837-3842.

10. Gould, W. D., Hagedorn, C., Bardinelli, T. R., and Zablotowicz, R. M. 1985. New selective media for enumeration and recovery of fluorescent pseudomonads from various habitats. Appl. Environ. Microbiol. 49:28-32.

11. Hair, W. M. 2001. Clemson canola information database. http://www.clemson.edu/edisto/can ola/guide.htm.

12. Hopkins, D. L., Lobinske, R. J., and Larkin, R. P. 1992. Selection for Fusarium oxysporum $\mathrm{f}$. sp. niveum race 2 in monocultures of watermelon cultivars resistant to Fusarium wilt. Phytopathology 82:290-293.

13. Jeffers, S. N., and Martin, S. B. 1986. Comparison of two media selective for Phytophthora and Pythium species. Plant Dis. 70:1038-1043.

14. Keinath, A. P., and DuBose, V. B. 2004. Evaluation of fungicides for prevention and management of powdery mildew on watermelon. Crop Prot. 23:35-42.

15. Kirkegaard, J. A., and Sarwar, M. 1998. Biofumigation potential of brassicas. I. Variation in plant glucosinolate profiles of diverse field grown brassicas. Plant Soil 201:71-89.

16. Komada, H. 1975. Development of selective medium for quantitative isolation of Fusarium oxysporum from natural soil. Rev. Plant Prot. Res. 8:114-123.

17. Kuehl, R. O. 2000. Design of Experiments: Statistical Principles of Research and Design Analysis. 2nd ed. Duxbury Press, Pacific Grove, CA.

18. Magrath, R., Herron, C., Giamoustaris, A., and Mithen, R. 1993. The inheritance of aliphatic glucosinolates in Brassica napus. Plant Breed. 111:55-72.

19. Manici, L. M., Lazzeri, L., Baruzzi, G., Leoni, O., Galletti, S., and Palmieri, S. 2000. Suppressive activity of some glucosinolate enzyme degradation products on Pythium irregulare and Rhizoctonia solani in sterile soil. Pest Manag. Sci. 56:921-926.

20. Martin, F. N. 1992. Pythium. Pages 39-49 in: Methods for Research on Soilborne Phytopathogenic Fungi. L. L. Singleton, J. D. Mihail, and C. M. Rush, eds. American Phytopathological Society, St. Paul, MN.

21. Mayton, H. S., Olivier, C., Vaughn, S. F., and Loria, R. 1996. Correlation of fungicidal activity of Brassica species with Allyl isothiocyanate production in macerated leaf tissue. Phytopathology 86:267-271.

22. Mazzola, M., and Mullinix, K. 2005. Comparative field efficacy of management strategies containing Brassica napus seed meal or green manure for the control of apple replant disease. Plant Dis. 89:1207-1213.

23. Morra, M. J., and Kirkegaard, J. A. 2002. Isothiocyanate released from soil-incorporated Brassica tissues. Soil Biol. Biochem. 34:16831690.

24. Njoroge, S., Riley, M. B., and Keinath, A. P. 2006. Effect of biofumigation with brassica crops on population densities of soilborne pathogens in South Carolina. (Abstr.) Phytopathology 96:S85.

25. Norsworthy, J. K., Brandenberger, L., Burgos, N. R., and Riley, M. 2005. Weed suppression in Vignia unguiculata with a spring seeded brassicacea green manure. Crop Prot. 24:441447.

26. Pinkerton, J. N., Ivors, K. L., Miller, M. L., and Moore, L. W. 2000. Effect of soil solarization and cover crops on populations of selected soilborne plant pathogens in western Oregon. Plant Dis. 84:952-960.

27. Ramirez-Villapudua, J., and Munnecke, D. E. 1987. Control of cabbage yellows (Fusarium oxysporum f. sp. conglutinans) by solar heating of field soils amended with dry cabbage residues. Plant Dis. 71:217-221.

28. Rodriguez-Kabana, R., Beute, M. K., and Backman, P. A. 1980. A method for estimating numbers of viable sclerotia of Sclerotium rolfsii in soil. Phytopathology 70:917-919.

29. Sarwar, M., and Kirkegaard, J. A. 1998. Biofumigation potential of brassicas: II. Effect of environment and ontogeny on glucosinolate production and implications for screening. Plant Soil 201:91-101.

30. Sarwar, M., Kirkegaard, J. A., Wong, P. T. W. and Desmarchelier, J. M. 1998. Biofumigation potential of brassicas. III. In vitro toxicity of isothiocyanates to soil-borne fungal pathogens. Plant Soil 201:103-112.

31. Scott, J. S., and Knudsen, G. R. 1999. Soil amendment effects of rape (Brassica napus) residues on pea rhizosphere bacteria. Soil Biol. Biochem. 31:1435-1441.

32. Smolinska, U. 2000. Survival of Sclerotium cepivorum sclerotia and Fusarium oxysporum chlamydospores in soil amended with cruciferous residues. J. Phytopathol. 148:343-349.

33. Smolinska, U., and Horbowicz, M. 1999. Fungicidal activity of volatiles from selected cruciferous plants against resting propagules of soil-borne fungal pathogens. J. Phytopathol. 147:119-124.

34. Smolinska, U., Morra, M. J., Knudsen, G. R., and Brown, P. D. 1997. Toxicity of glucosinolate degradation products from Brassica napus seed meal toward Aphanomyces euteiches f. sp. pisi. Phytopathology 87:77-82.

35. Smolinska, U., Morra, M. J., Knudsen, G. R., and James, R. L. 2003. Isothiocyanates produced by brassicaceae species as inhibitors of Fusarium oxysporum. Plant Dis. 87:407-412.

36. Subbarao, K. V., Hubbard, J. C., and Koike, S. T. 1999. Evaluation of broccoli residue incorporation into field soil for Verticillium wilt control in cauliflower. Plant Dis. 83:124-129.

37. Takehara, T., Hanzawa, S., Funabara, M., Nakaho, K., and Nakagawa, A. 2004. Control of soilborne pathogens using allelopathic plants to lower redox potential of soil. (Abstr.) Phytopathology 94:S101.

38. Trujillo, E. E., Calvin, C. A., Aragaki, M., and Yoshimura, M. A. 1987. Ethanol-potassium nitrate medium for enumerating Rhizoctonia solani-like fungi from soil. Plant Dis. 71:10981100 .

39. van Bruggen, A. H. C., and Arneson, P. A. 1986. Quantitative recovery of Rhizoctonia solani from soil. Plant Dis. 70:320-323.

40. Van der Plaats-Niterink, A. J. 1981. Monograph of the genus Pythium. Studies in Mycology No. 21. Centraalbureau Voor Schimmelcultures, Baarn, The Netherlands.

41. Zasada, I. A., Ferris, H., Elmore, C. L., Roncoroni, J. A., MacDonald, J. D., Bolkran, L. R., and Yakabe, L. E. 2003. Field application of brassicaceous amendments for control of soilborne pests and pathogens. Online. Plant Health Progress doi:10.1094/PHP-2003-112001-RS.

42. Zhou, X. G., and Everts, K. L. 2003. Races and inoculum density of Fusarium oxysporum f. sp. niveum in commercial watermelon fields in Maryland and Delaware. Plant Dis. 87:692 698.

43. Zhou, X. G., and Everts, K. L. 2004. Suppression of Fusarium wilt of watermelon using soil amendment with hairy vetch. Plant Dis. 88:1357-1365. 